\title{
Relationship Among Sea Surface Temperature, ENSO and Indian Ocean Dipole in the Indian Ocean: A Clue to Recognizing Convective Systems
}

\author{
B.R. Manjunatha ${ }^{*}, 1$ K.M. Krishna ${ }^{2}$ and Y.N. Raju ${ }^{2}$ \\ ${ }^{1}$ Dept of Marine Geology, Mangalore University, Mangalagangotri, India \\ ${ }^{2}$ Dept of Meteorology and Oceanography, Andhra University, Visakhapatnam, India
}

\begin{abstract}
The Northern Indian Ocean is unique in the global ocean because of seasonal reversal of winds as well as surface ocean currents. In the southern part of the Indian Ocean, a significant ocean-atmospheric phenomenon developed just like an El Nino phenomenon noticed in the Pacific Ocean. This phenomenon is known as the Indian Ocean Dipole. In this study we investigate the relationship between IOD and El Nino with sea surface temperature in identifying surface ocean convective cells those strengthens the monsoon.
\end{abstract}

Keywords: El nino, indian ocean dipole, indian ocean, lanina, sea surface temperature.

\section{INTRODUCTION}

In the realm of all tropical oceans, Indian Ocean not characterized by a single mode of variability, but also has several interacting processes. It strongly interacts with Asian monsoon through its circulation with the support of sea surface temperature anomalies and heat content. The dominant patterns of sea surface temperature (SST) in the tropical Indian Ocean varies seasonally, however, it is much weaker than that of the Pacific Ocean.

The SST over the eastern and western Indian Ocean shows a peculiar characteristics during the Fall season (September, October and November). Saji [1-2] suggested that it is an ocean-atmosphere coupled mode originates in the Indian Ocean climate system. They also observed that it has a characteristic seasonal phase locking system. This mode is referred as the "dipole mode" (DM). The spatial DM pattern that they proposed is characterized by sea surface temperature anomalies (SSTAs) which is an important sign in the south-eastern tropical Indian Ocean $\left(10^{\circ} \mathrm{S}-0^{\circ}, 90^{\circ} \mathrm{E}-110^{\circ} \mathrm{E}\right)$. However, the SSTAs western tropical Indian Ocean is in the opposite sign (Western tropical Indian Ocean; $\left.10^{\circ} \mathrm{S}-10^{\circ} \mathrm{N}, 50^{\circ}-70^{\circ} \mathrm{E}\right)$. However, the existence of a dipole as a SST mode is an independent of system of ENSO, which is currently a subject of discussion. Furthermore, it is argued that the IOD is independent of ENSO. Several studies [3-6] indicate that the sea surface temperature anomaly (SSTA) characterizing the IOD in the tropical Indian Ocean. The SST variability in the eastern and western parts of the tropical Indian Ocean during IOD is somewhat controversial. The composite analysis of [7]

*Address correspondence to this author at the Dept of Marine Geology, Mangalore University, Mangalagangotri, India;

E-mail: omsrbmanju@yahoo.com implies an out of SSTA phase relationship between the eastern and western Indian Ocean. Furthermore, there is no statistically significant correlation of SSTAs between the western and eastern parts of the Indian Ocean. This suggests that IOD must be a zonal perturbation gradient [4]. Another significant feature that occurs in the atmosphere-ocean interaction in the tropical Pacific Ocean that affects the global climate is El Nino-Southern Oscillation (ENSO) phenomenon. Several investigations suggest that ENSO also regulate the Indian Ocean in different ways [8-12]. Some studies suggest that a significant fraction of the SST variability in the Indian Ocean is related to ENSO, however, there are additional factors to be considered important in regulating the SST anomalies [13]. Another issue that much debated is the relation of IOD events with ENSO. The IOD is an inherent coupled mode of the Indian Ocean, however, seems to be independent of ENSO. Saji [7] noted that many positive IOD events nether related to El Nino nor La Nina condition. Further, they pointed out that the monthly time series of the zonal SSTs gradient referred as the dipole mode index (DMI), which is only moderately correlated with the Nino $\sim 0-3\left(5^{\circ} \mathrm{N}-5^{\circ} \mathrm{S}, 90^{\circ}-150^{\circ} \mathrm{W}\right)$ index, however, the DMI and equatorial winds over the Indian Ocean (Ueq) are more strongly correlated. Webster [2] studied wind, SST, and outgoing long wave radiation (OLR) anomalies to demonstrate the role of wind-forced ocean dynamics in the origin IOD. Conversely, the SSTAs, OLR and wind fields are interrealted. Allan [14] provide an evidence that supports the dependence ENSO and Indian Ocean Dipole (IOD). Saji [1] found negative correlations between western Indian Ocean and the Eastern Indian Ocean only when the interdecadal anomaly is removed. Though there is a suggestion that this is mostly true only for the latter half of the record, when there is a rapid warming of the mean SST in both the western and eastern TIO. The main objective of the study is 
a thorough examination of the spatial structure of IOD variability in Indian Ocean SST and their relation to El Nino variability.

\section{DATA AND METHODOLOGY}

For this study we used UK Met Office Hadley sea surface temperature (HadIsst1) that span the period from 1870-2013 [15]. The Met Office Hadley Centre's sea surface temperature (SST) data set, HadISST1, replaces the Global Sea Surface Temperature (GISST) data sets, and is a unique combination of monthly globally-complete fields of SST and sea ice concentration on a 1 degree latitude-longitude grid. In order to enhance data coverage, monthly median SSTs for 1871-1995 from the Comprehensive Ocean-Atmosphere Data Set (COADS) were also used where there were no marine data bank data. HadISST1 temperatures are reconstructed using a two stage reduced-space optimal interpolation procedure, followed by superposition of quality-improved gridded observations onto the reconstructions to restore local detail. (http://www.metoffice. gov.uk/hadobs/hadisst/).

The sea surface temperature anomaly is calculated from the mean value of neutral and neutral IOD years. The El Nino, La Nina, neutral, positive, negative and neutral IODs are taken from Sakova [16] and they are shown in Table 1. In this study the season are taken four types 1. JanuaryFebruary (JF), 2. March-April-May (MAM), 3. June-JulyAugust-September (JJAS) and 4. October-NovemberDecember (OND).

\section{RESULTS AND DISCUSSION}

The mean seasonal SSTAs anomalies during positive IOD are in accordance with El Nino years (Fig. 1). The

Table 1. Classification of years of positive/negative IOD along with EI Niño and La Niña events (after Sakova, 2010).

\begin{tabular}{|c|c|c|c|}
\hline & Negative IOD & Neutral & Positive IOD \\
\hline El Nino & 1930 & $\begin{array}{c}1877,1888,1899,1905,1911,1914,1918,1925,1940,1941,1965, \\
1972,1986,1987\end{array}$ & $\begin{array}{c}1896,1902,1957,1963,1982,1991, \\
1997\end{array}$ \\
\hline Neutral & $\begin{array}{l}1915,1958,1968,1974 \\
1980,1985,1989,1992\end{array}$ & $\begin{array}{c}1880,1881,1882,1883,1884,1895,1898,1900,1901,1904,1907, \\
1908,1912,1920,1921,1927,1929,1931,1932,1934,1936,1937, \\
1939,1943,1947,1948,1951,1952,1953,1959,1960,1962,1966, \\
1967,1969,1971,1976,1977,1979,1983,1990,1993,1995,2001, \\
2002,2003,2005,2006\end{array}$ & $\begin{array}{l}1885,1887,1891, \\
1894,1913,1919, \\
1923,1926,1935, \\
1944,1945,1946, \\
1961,1994,2004\end{array}$ \\
\hline La Nina & $\begin{array}{c}1906,1909,1916,1917 \\
1933,1942,1975\end{array}$ & $\begin{array}{c}1878,1879,1886,1889,1890,1892,1893,1897,1903,1910,1922, \\
1924,1928,1938,1949,1950,1954,1955,1956,1964,1970,1973, \\
1978,1981,1984,1988,1996,1998,2000\end{array}$ & 1999 \\
\hline
\end{tabular}
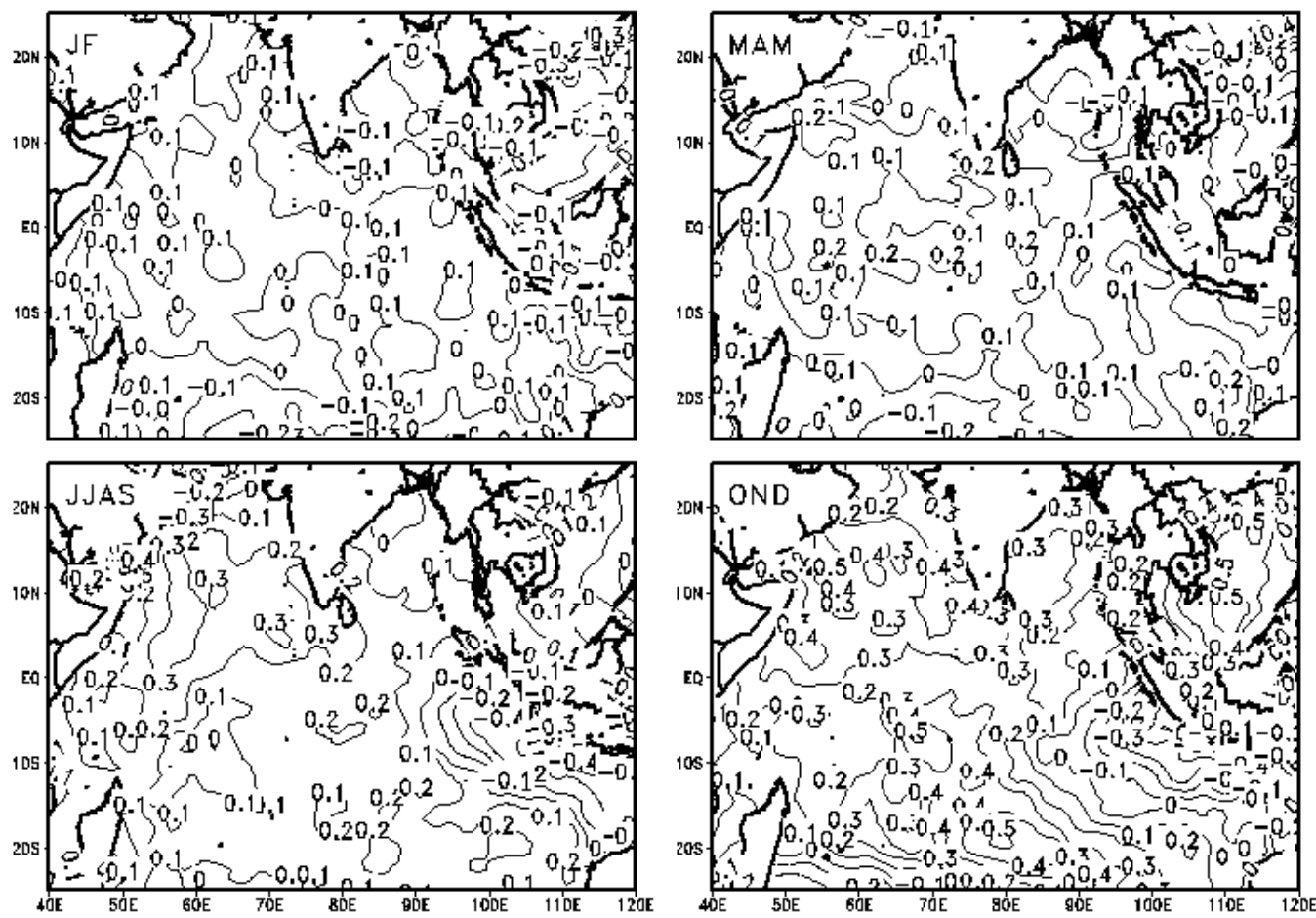

Fig. (1). Seasonal sea surface temperature anomaly during positive IOD with co-occurof El Nino years. 
SSTAS distributions in the south-west Bay of Bengal, Off Java and south of $20^{\circ} \mathrm{S}$, particularly at the western part of the Indian Ocean show cooling trend during January and February. During the spring (March, April and May) the situation is similar at the south of $20^{\circ} \mathrm{S}$ latitude. In contrast, the SSTAS increases in the western part and equatorial region of the Indian Ocean, north off the Somalia and southwest coast of India.

In the previous season (winter), cool SSTAs are shifted towards Myanmar and Burma Coasts in the Bay of Bengal. New cooling spots are developed in the northern Arabian Sea. The magnitude of the cooling of Arabian Sea is similar to that noticed in the Bay of Bengal.

During summer season (June, July, August and September) the mild warm SSTAs in the northern and eastern Arabian Sea are replaced with strong cool SSTAs anomalies $\left(-0.3^{\circ} \mathrm{C}\right.$ and $-0.4^{\circ} \mathrm{C}$ respectively). However, SSTAs tends to increase around $0.3^{\circ} \mathrm{C}$ along the south-west off India, central and western Arabian Sea. These anomalous conditions favorable for an intense convective activity. The similar spatial distributions trend of SSTAs continued during the fall season (October, November and December). This warm anomaly is significant $\left(0.5^{\circ} \mathrm{C}\right)$ along the SeychellesChagos Ridge western Arabian Sea as well as off Sri Lanka. The seasonal distributions of SSTAs during the positive IOD and neutral years are shown In Fig. (2). During the winter season (January and February), the entire eastern Indian Ocean (south of $20^{\circ} \mathrm{S}$ to north of $20^{\circ} \mathrm{N}$ ) characterized by the cool SSTAs, while, western Indian Ocean records the warm
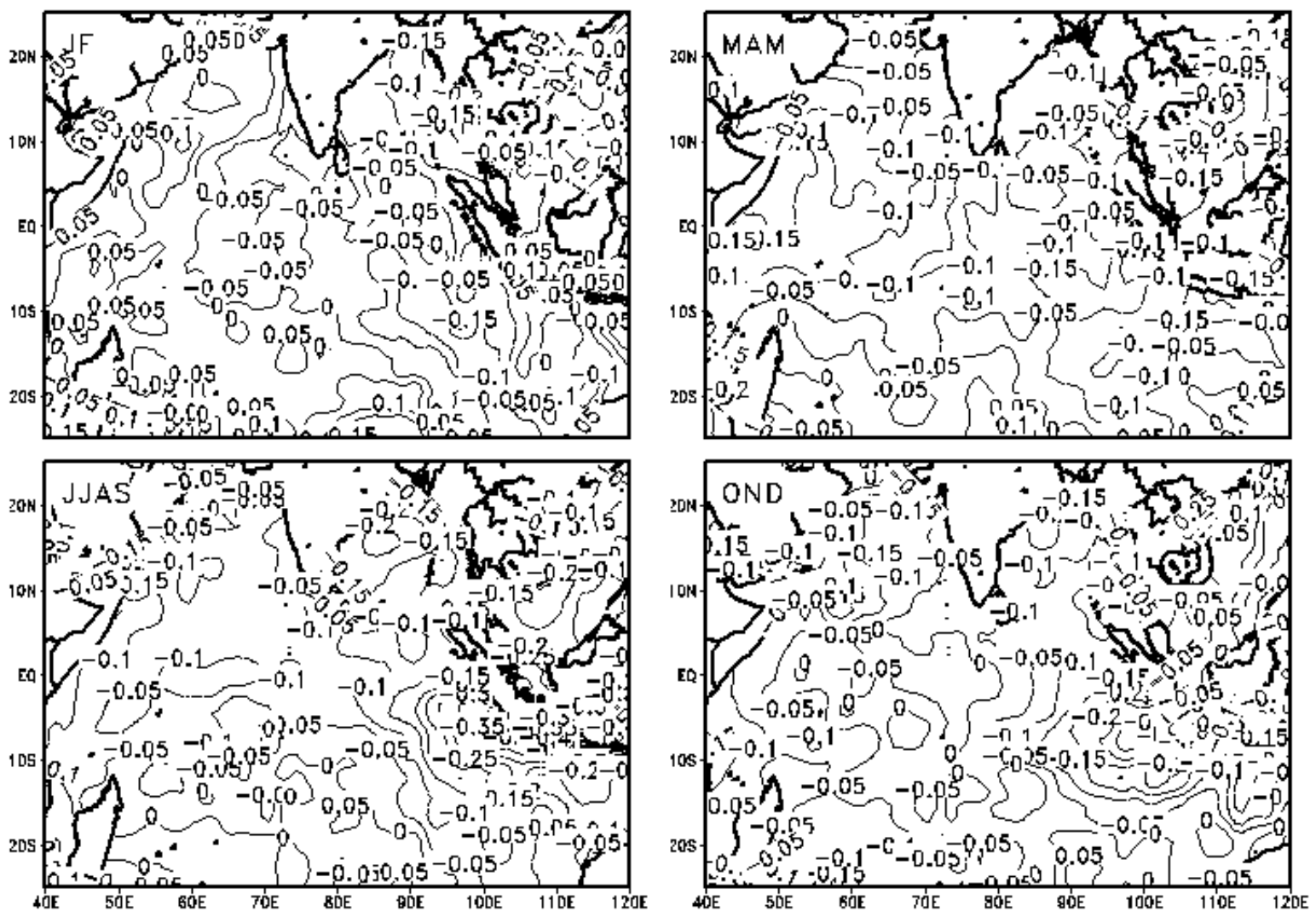

SSTAs. These conditions continue to be prevailed during the spring season (March, April and May). However, the cool SSTAs further extended to the entire Indian Ocean with the exception of the western Arabian Sea. During the summer season (June, July, August and September), cooling is noticed in the entire Indian Ocean. Along the eastern Arabian Sea and upper part of the Bay of Bengal areas, significant cooling noticed $\left(-0.2^{\circ} \mathrm{C}\right.$ to $\left.-0.35^{\circ} \mathrm{C}\right)$. The deep cooling among these regions weakens a bit during the fall season (October, November and December).

During winter (January and February) season when the positive IOD and co-occurrance of La Nina phenomenon occur in the Pacific Ocean, the SSTAs are warmer $\left(0.5^{\circ} \mathrm{C}\right)$ from the equator to the north of $20^{\circ} \mathrm{N}$ latitude (Fig. 3). It is quite different when compared to the previous conditions and the warm SSTAs are higher than the positive IOD with co-occurrence El Nino condition. This indicates that ocean is very much favorable for the convective activity that would strengthen the monsoon activity over the Indian subcontinent. In contrast, the entire reverse conditions observed in the south of $10^{\circ} \mathrm{S}$ latitude. It performs just like an electric dipole (north-south variations). Similarly, spatial variations are continued during the spring (March, April and May), however, the SSTAs variations in both northern and southern Indian Ocean are not considerably great as compared to those observed during the winter (January and February), with the exception in the western Arabian Sea. The SSTAs off southwest coast of Indian and Sri Lankan dome further increased to $0.4^{\circ} \mathrm{C}$ to $0.8^{\circ} \mathrm{C}$ during the summer. These

Fig. (2). Similar to Fig. (1) but for positive IOD and neutral years 

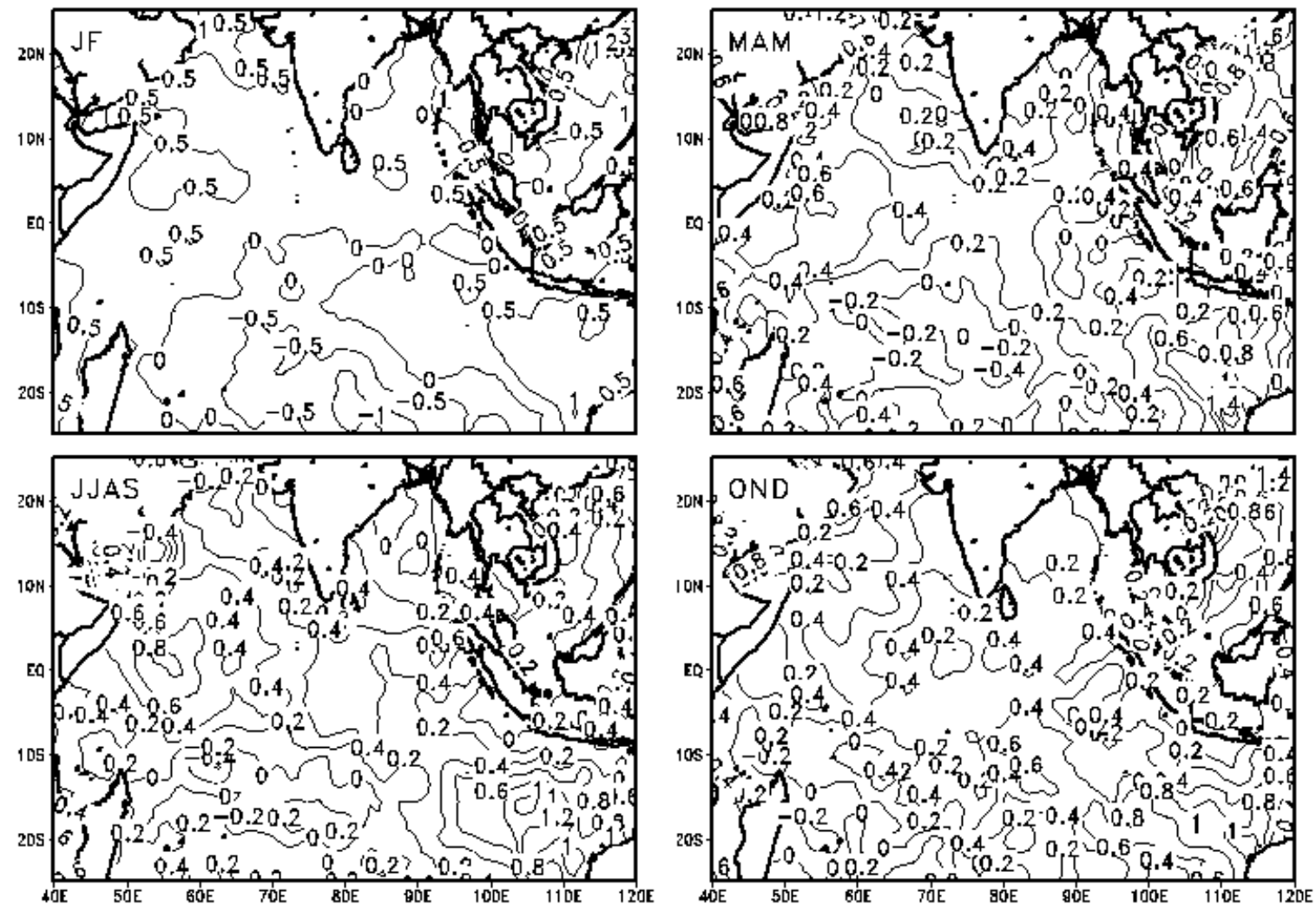

Fig. (3). Similar to Fig. (1) but for positive IOD and La Nina years.

conditions again favourable for further strengthening the Asian monsoon. Strong cooling $\left(-0.2^{\circ} \mathrm{C}\right.$ to $\left.-0.4^{\circ} \mathrm{C}\right)$ is observed from $10^{\circ} \mathrm{S}-10^{\circ} \mathrm{N}$ latitude sector along the western Arabian Sea and southern Indian Ocean. During the fall season, the SSTAs increases in entire Indian Ocean, barring north-east off Madagascar Island.

During winter season when the negative IOD co-occur with La Nina conditions (Fig. 4), entire Indian Ocean becomes reverse conditions as compared to positive IOD with El Nino years (Fig. 1). The two northern limbs of the Northern Indian Ocean - Arabian Sea and the Bay of Bengal show contrasting SSTAs distributions - when strong cooling noticed in the Arabian Sea, the Bay of Bengal shows warming signature. Similarly, In the southern Indian Ocean, western part shows a strong cooling while, the eastern part shows warming SSTAs.

During the spring season, the spatial distributions of SSTAs are similar to that observed in the northern Indian Ocean. In the western part of the Northern Indian Ocean, SSTAs weakens to half of its previous values. The decrease in the SSTAs are gradually replaced by the warm anomalies along the equatorial Indian Ocean. However, south of $20^{\circ} \mathrm{S}$, SSTAs tend to be decreased during the spring season. Deep cooling observed in the entire northern India Ocean including the western part. Warm SSTAs are replaced with cool anomalies in the eastern part of the Indian Ocean, however, along the Seychelles-Chagos Thermocline Ridge and off African Coast (south of $5^{\circ} \mathrm{S}$ ) warm SSTAs noticed

$\left(0.2^{\circ} \mathrm{C}-0.6^{\circ} \mathrm{C}\right)$. During the winter season, the warm SSTAs observed in the entire Indian Ocean with the exception the central Arabian Sea and eastern region.

During the winter season, the warm SSTAs observed in the Indian Ocean barring the Seychelles-Chagos Thermocline Ridge area during negative IOD with neutral conditions (Fig. 5). This warm signal is weak over the entire northern Indian Ocean. The same conditions continued during the spring season and almost neutral signal in the northern Indian Ocean. However, south of $20^{\circ} \mathrm{S}$, cool SSTAs further strengthen. During the summer season and to some extent fall season, both western and eastern regions, as well as the northern Indian Ocean tend to be warming $\left(0.3^{0} \mathrm{C}\right)$, while, cooling continue to extended from the south of $20^{\circ} \mathrm{S}$ to the Seychelles-Chagos Thermocline Ridge.

During the winter season of negative IOD and La Nina years (Fig. 6), the cooling found to be observed over the entire Indian Ocean, particularly in the central Bay of Bengal. Similar conditions observed during the spring season, however, the strongest cooling noticed at the western Arabian Sea. While during summer season, cooling in the Indian Ocean occurs with the exception of eastern part with strongest cooling observed at western part $\left(-0.4^{\circ} \mathrm{C}\right)$. During the winter season, the SSTAs weakens along the eastern part, while stronger at the western Arabian Sea $\left(-0.5^{\circ} \mathrm{C}\right)$. Nevertheless, during all seasons associated the neutral IOD with El Nino and La Nina years, negative SSTs observed in the Indian Ocean (Figs. 7, 8). 

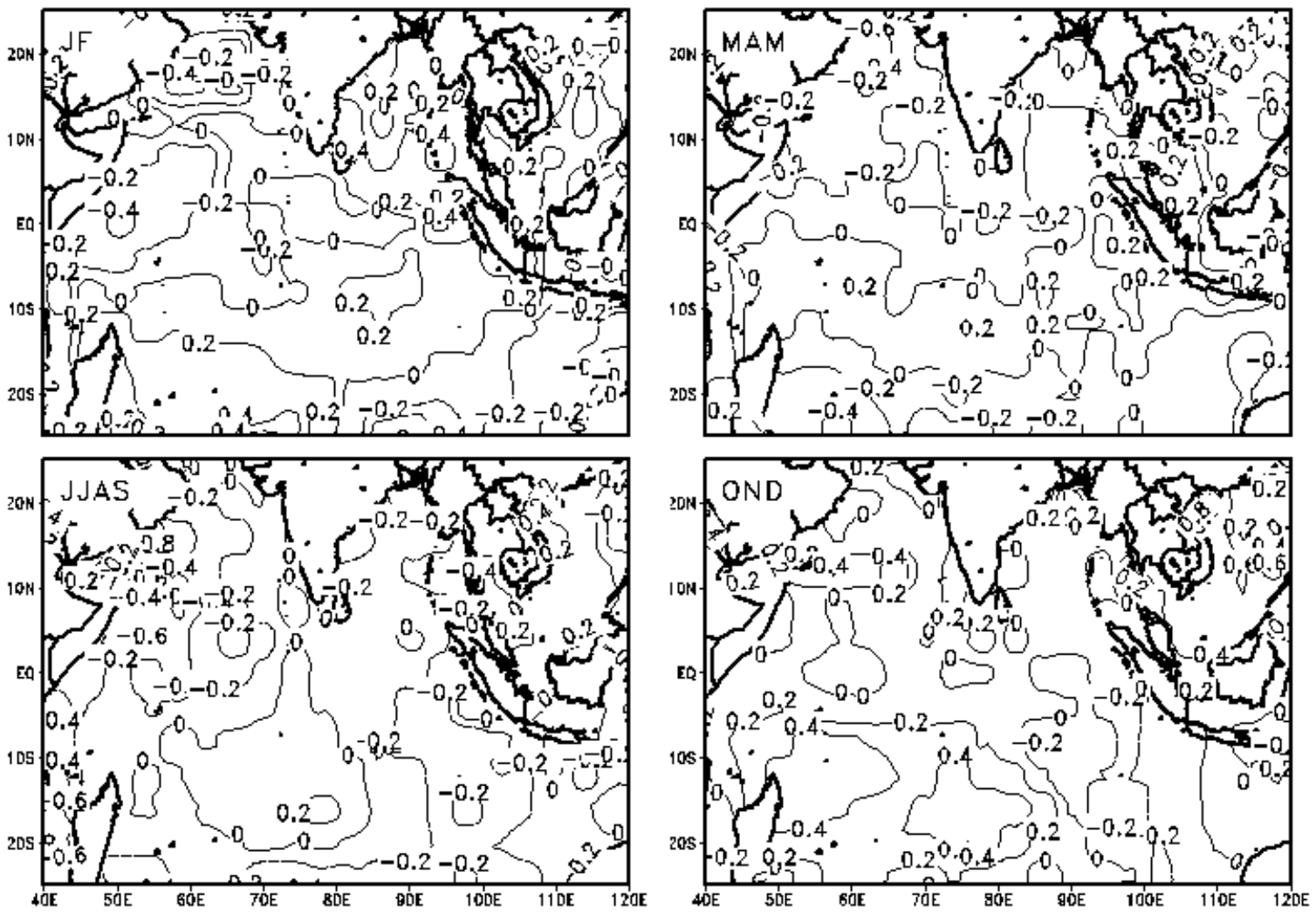

Fig. (4). Similar to Fig. (1) but for negative IOD and El Nino years.
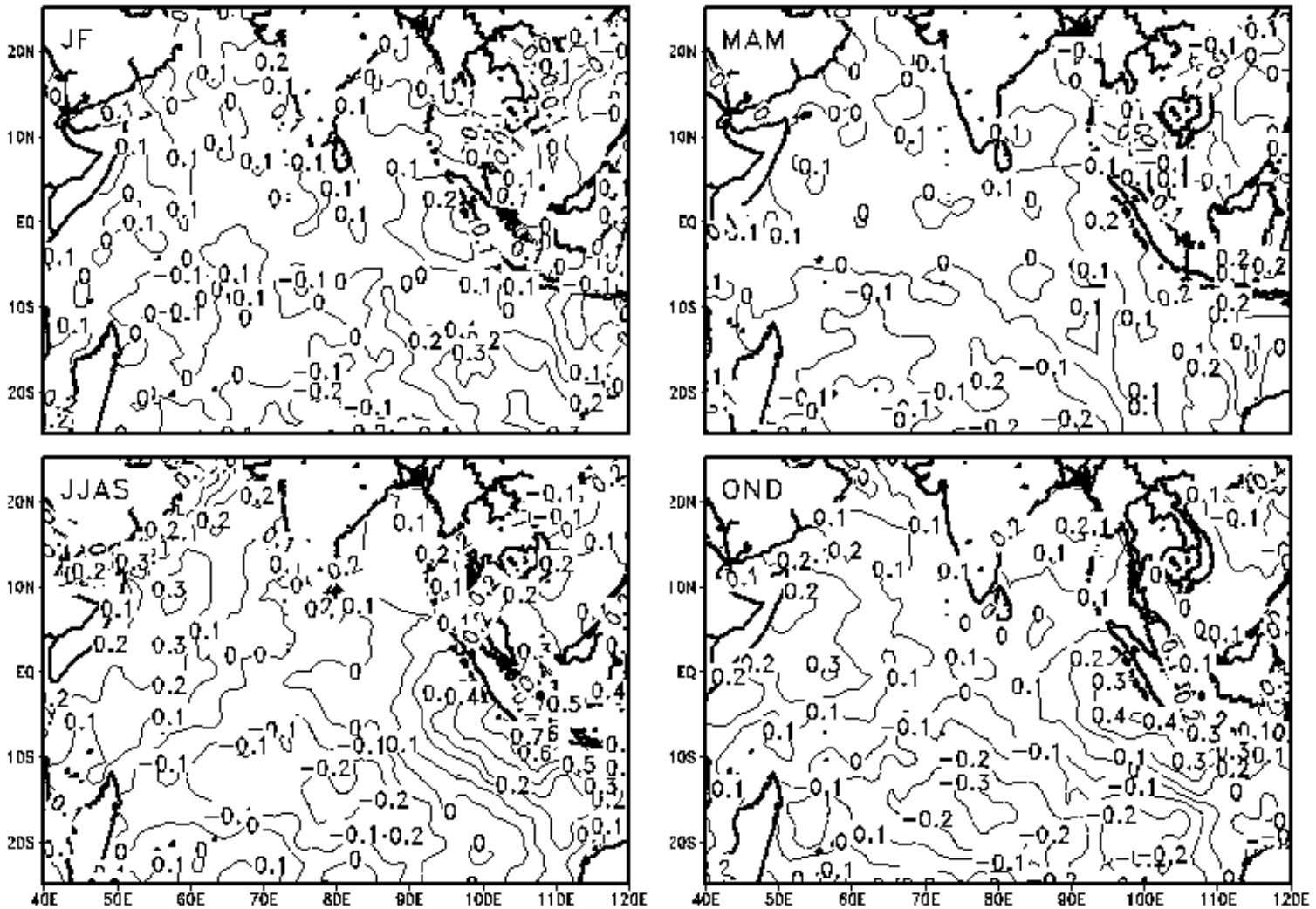

Fig. (5). Similar to Fig. (1) but for negative IOD and neutral years. 

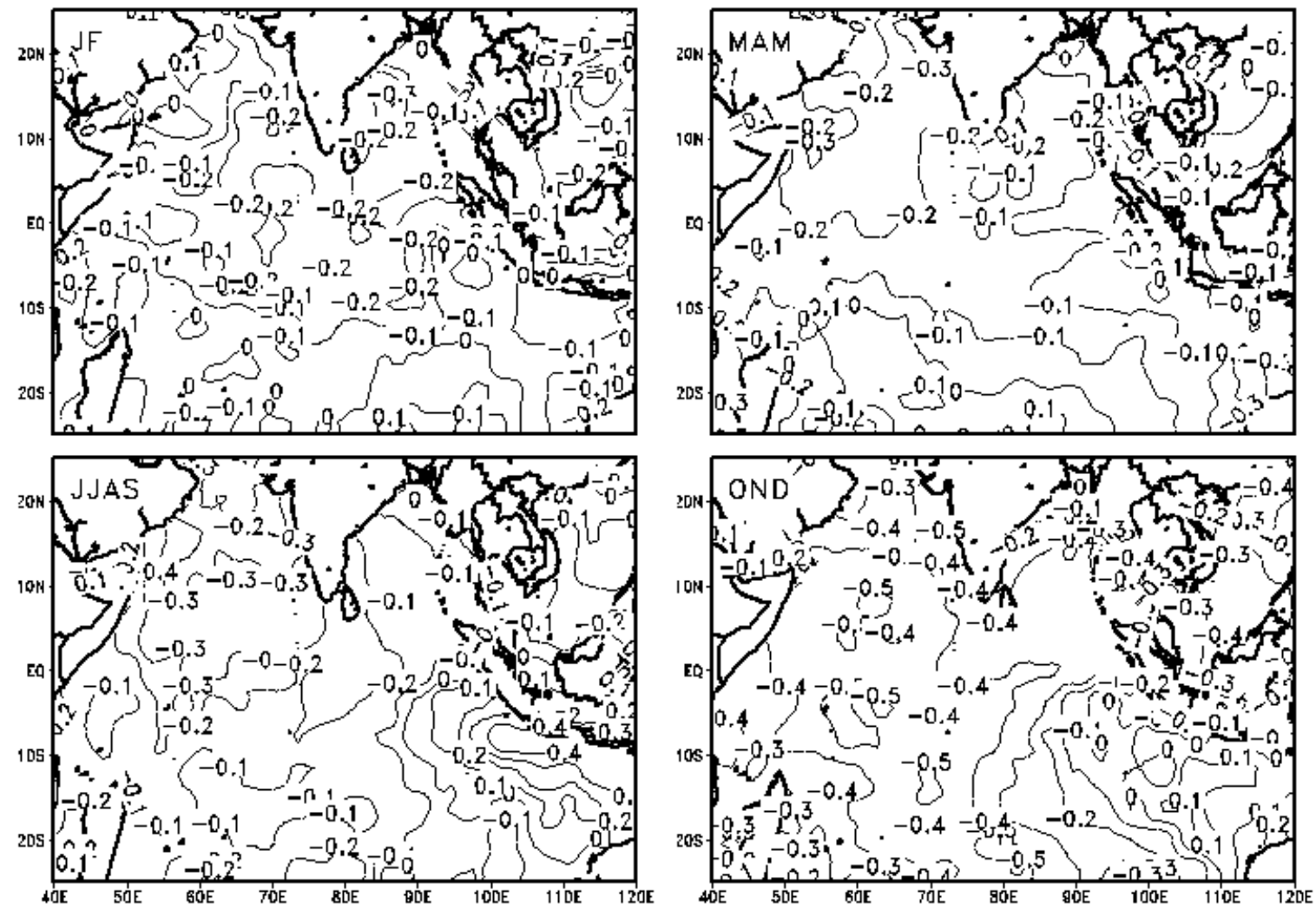

Fig. (6). Similar to Fig. (1) but for negative IOD and La Nina years.
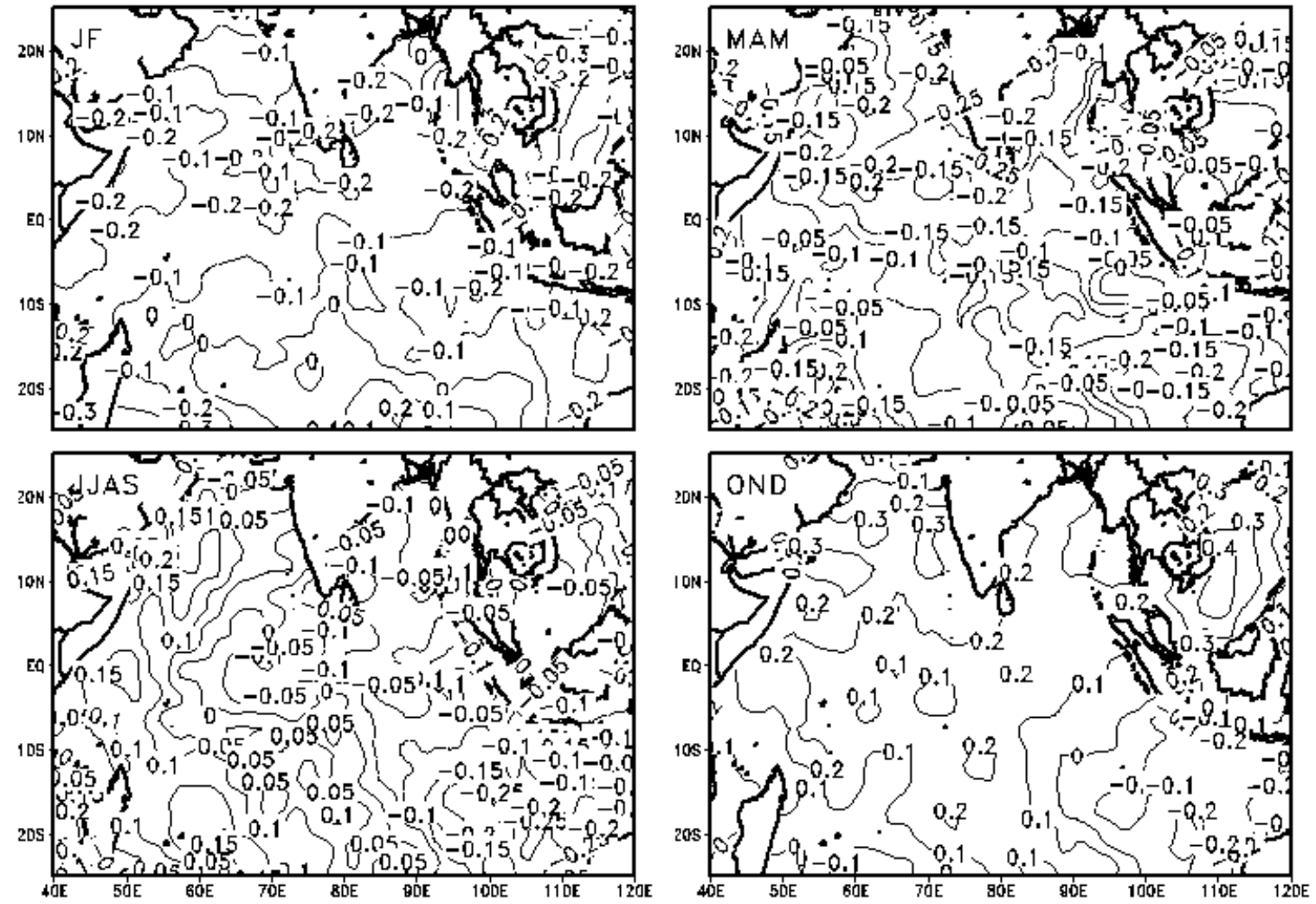

Fig. (7). Similar to Fig. (1) but for neutral IOD and El Nino years. 

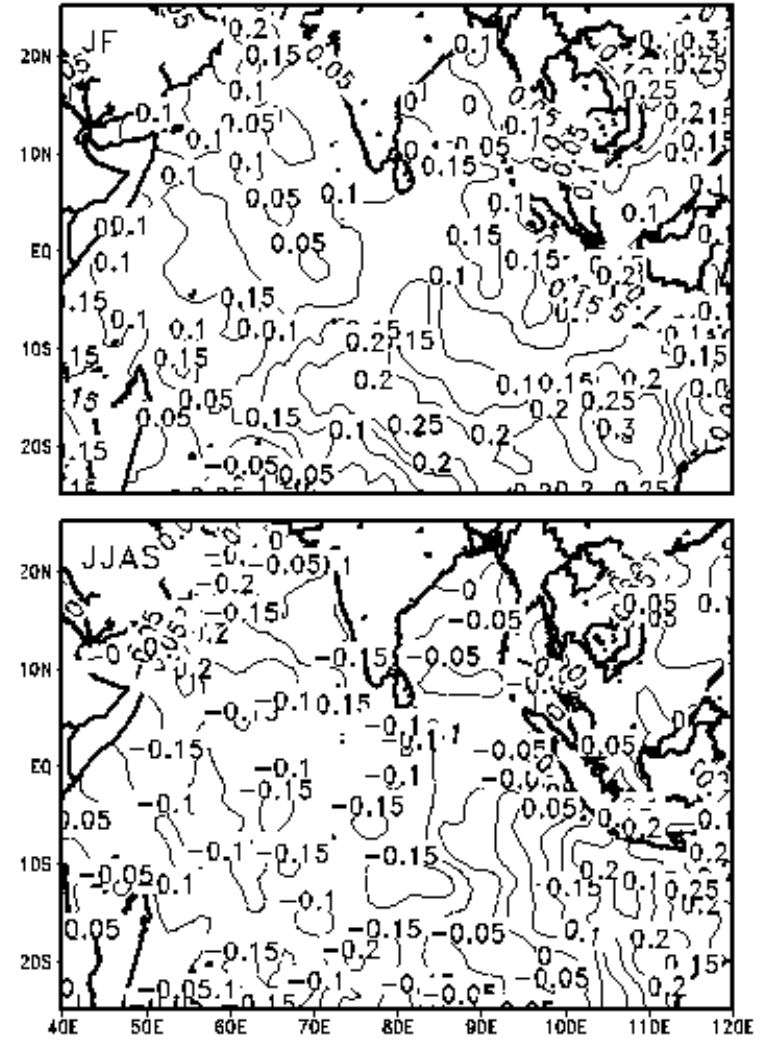

Fig. (8). Similar to Fig. (1) but for neutral IOD and La Nina years.

\section{CONCLUSION}

The distributions of sea surface temperature anomalies in the Indian Ocean have been analyzed for over period of 144 years from 1870 to 2013. During the positive IOD + El Nino, positive IOD + neutral, positive IOD + La Nina, negative IOD + El Nino, negative IOD + neutral, negative IOD + La Nina, neutral IOD + El Nino and neural IOD + La Nina years noticed. Besides these, a strong convective regions identified along the eastern Arabian Sea and the Bay of Bengal suggesting for a detailed investigation.

\section{CONFLICT OF INTEREST}

The authors confirms that this article content has no conflict of interest.

\section{ACKNOWLEDGEMENTS}

The authors are thankful to U.K. Met Office for providing the sea surface temperature data for this study. We also extend our gratitude to two anonymous reviewers for their constructive comments and suggestions on the earlier version of this manuscript, which will help significantly to improve the quality of the manuscript.

\section{REFERENCES}

[1] Saji NH, Yamagata T. Structure of SST and surface wind variability during Indian Ocean dipole mode events: COADS Observations, J Clim 2003; 16: 2735-51.

[2] Webster PJ, Moore AM, Loschnigg JP, Leben RR. Coupled oceanatmosphere dynamics in the Indian Ocean during 1997-98. Nature 1999; 401: 356-360
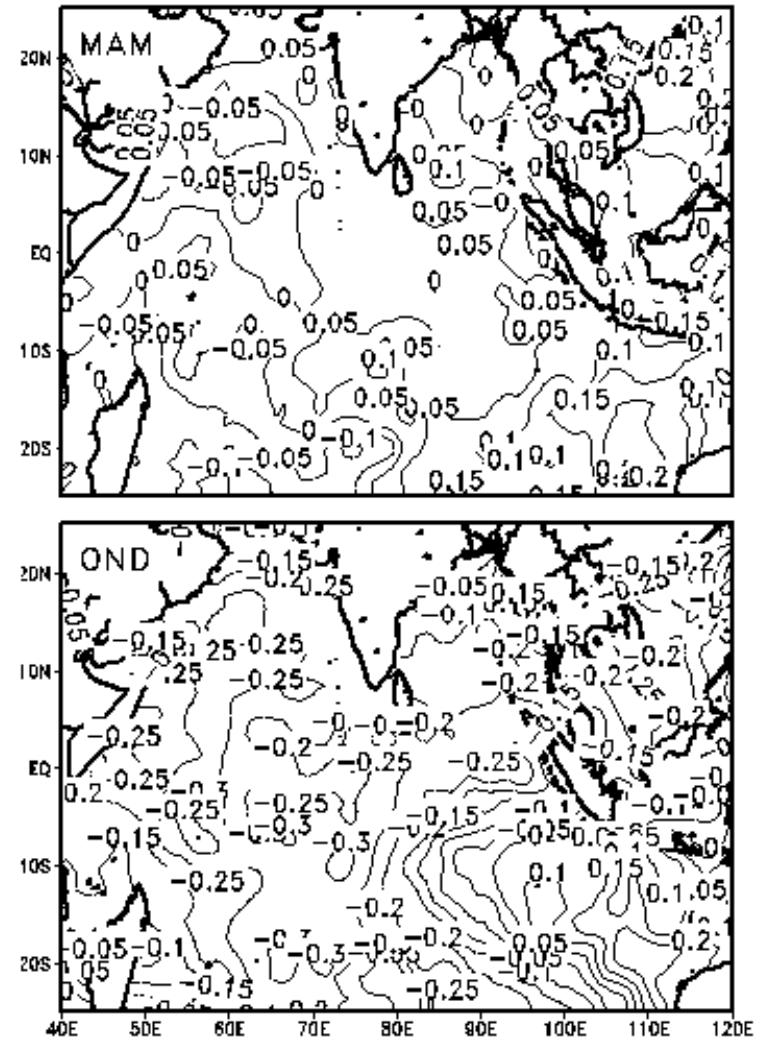

[3] Reverdin G, Cadet DL, Gutzler D. Interannual displacements of convection and surface circulation over the equatorial Indian Ocean. Quart J Roy Meteor Soc 1986; 112: 43-67.

[4] Hastenrath S, Nicklis A, Greischar L. Atmospheric-hydrospheric mechanisms of climate anomalies in the western equatorial Indian Ocean. J. Geophys. Res., 1993; 98: 20219-35.

[5] Meyers G, McIntosh P, Pigot L, Pook M. The years of El Niño, La Niña and interactions with the tropical Indian Ocean. J Clim 2007; 20: $2872-80$

[6] Meyers G. Variation of Indonesian throughflow and the El NiñoSouthern Oscillation. J. Geophys. Res 1996; 101: 12255-63.

[7] Saji N.H, Goswami BN, Vinayachandran PN, Yamagata T. A dipole mode in the tropical Indian Ocean. Nature 1999; 401: 360-3.

[8] Latif M, Barnett TP. Interactions of the tropical oceans. J Climate, 1995; 8: 952-64.

[9] Tourre YM, White WB. Evolution of ENSO signals over the IndoPacific domain. J Phys Oceanogr 1997; 27: 683-96.

[10] Chambers DP, Tapley BD, Stewart RH. Anomalous warming in the Indian Ocean coincident with El Niño. J Geophys Res 1999; 104 (C2): 3035-47.

[11] Hastenrath S. Dipoles, temperature gradients and tropical climate anomalies. Bull Amer Meteor Soc 2002; 83: 735-8.

[12] Venzke S, Latif M, Villwock A. The coupled GCM ECHO-2. Part II: Indian Ocean response to ENSO. J Clim 2000; 13: 1371-83.

[13] Murtugudde $\mathrm{R}$, Busalacchi A. Interannual variability of the dynamics and thermodynamics of the tropical Indian Ocean. J. Climate 1999; 12: 2300-26.

[14] Allan R, Coauthors. Is there an Indian Ocean dipole, and is it independent of the El Niñ-Southern Oscillation? CLIVAR Exch. 2001; 6 (3): 18-22.

[15] Rayner NA, Parker DE, Horton EB, Folland CK, Alexander LV, Rowell DP, Kent EC, Kaplan A. Global analyses of sea surface temperature, sea ice, and night marine air temperature since the late nineteenth century. J Geophys Res (Atmospheres) 2003; 108(14): $2-1$. 
[16] Sakova IV. Low-frequency modes of variability of the Indian Ocean and their connection with the Indian Ocean Dipole. Ph.D thesis, 2010.

Received: July 23, 2014

Revised: August 07, 2014

Accepted: August 08, 2014

(C) Manjunatha et al.; Licensee Bentham Open.

This is an open access article licensed under the terms of the Creative Commons Attribution Non-Commercial License (http://creativecommons.org/licenses/by-nc/3.0/) which permits unrestricted, non-commercial use, distribution and reproduction in any medium, provided the work is properly cited. 